\title{
Floristic Diversity and Vegetation Analysis of Wadi Sudr, South-West Sinai Peninsula.
}

\author{
Amal A. Morsy ${ }^{1}$, Hemat K. Khatab ${ }^{1}$, Esraa A. El Sherbiny ${ }^{2}$, Jasmin E. \\ Eldemirdash \\ ${ }^{1}$ Faculty of Science- Ain Shams University. \\ ${ }^{2}$ Ecology and dryland agriculture division, Desert Research Center.
}

Amal A. Morsy, Hemat K. Khatab, Esraa A. El Sherbiny, Jasmin E. Eldemirdash, 2015. Floristic Diversity and Vegetation Analysis of Wadi Sudr, SouthWest Sinai Peninsula. Taeckholmia 35: 99-119.

\begin{abstract}
$T_{\text {his study evaluated the effect of edaphic factors on species }}$ diversity and distribution of vegetation in Wadi Sudr, Sinai Peninsula. The study included 21 stands, 54 species belonging to 44 genera and representing 22 families, where the abundant family was Zygophyllaceae comprising 15\% of the total number of the recorded species. Chamaephytes were the dominant life forms in the studied Wadi (55.56\%). Chorological analysis showed the dominance of the monoregional Saharo-Arabian chorotype (46.3\%). TWINSPAN classification separated five vegetation groups which included: (I) Zygophyllum album, (II) Haloxylon salicornicum, (III) Retama raetam, (IV) Reaumuria hirtella and (V) $R$. raetam. CCA analysis indicated that the vegetation group representing the downstream of Wadi Sudr was affected by soil chemical properties, whereas $\mathrm{CaCO}_{3} \%$ and physical properties affected the vegetation groups representing the up and midstream parts of the Wadi.
\end{abstract}

Key words: CCA, Sinai Peninsula, TWINSPAN, Vegetation, Wadi Sudr. 


\section{Introduction}

Wadi Sudr is one of the largest and most developed Wadis of the southern section of the western coast of Sinai, Girgis \& Ahmed (1985) stated that the vegetation of $\mathrm{W}$. Sudr is relatively rich in the variety of communities and species and also in having wide tracts covered by welldeveloped plant communities. This is attributed to its extensive water resources, the broadness of the channel, the friable nature of the sediments, and variation in the thickness of the surface deposits and presence of local stonypasts. They also determined three main sectors in W. Sudr; upstream dominated by Tamarix nilotica, Retama raetam and Haloxylon salicornicum, midstream dominated by $R$. raetam and downstream dominated by Tamarix aphylla.

Change in the existent components of a natural ecosystem, especially plants and soil, leads to gradual variations in the shape, composition and structure of such communities. Establishment, growth, regeneration, and distribution of the plant communities in the Wadis are controlled by many factors such as geographical position, physiographic features and human impact (Shaltout \& El-Sheikh, 2003; Korkmaz \& Ozcelik, 2013). Therefore, studying the classification and the inter-relation between the different plants communities in response to the environmental factors are a demand (Jafari et al., 2003). Inter-relationships between plant communities and environmental factors are complex, reflecting simultaneous changes in factors such as ground-water depth, soil moisture, soil stability and salt content (Zhang et al., 2005). Zegeye et al. (2006) showed that the interdependency of vegetation type and soil chemical properties lead to a variety of species, vegetation types and distribution of plant communities. Recently, multivariate analysis techniques were extensively used to elucidate these relationships, e.g., Moustafa \& Zaghloul (1996), Ali (2004), Morsy et al. (2010), Abd El-Ghani et al. (2013) and Salama et al. (2013).

The objective of the present study is to (1) analyze the vegetation of W. Sudr, and to (2) assess the correlation between the environmental factors which control the vegetation and to identify the regional plant communities.

\section{Study Area}

Wadi Sudr is located in the southern section of the western coast of Sinai, and lies between latitudes $29^{\circ} 36^{\prime} 32^{\prime \prime}-29^{\circ} 57^{\prime} 43^{\prime \prime} \mathrm{N}$, and longitudes $32^{\circ} 41^{\prime} 28^{\prime \prime}-32^{\circ} 17^{\prime} 27^{\prime \prime}$ E. It is bounded by Gebel El Raha (c. $600 \mathrm{~m}$ ) in the 
north and Sinn Bishr (c. $618 \mathrm{~m}$ ) in the south (Figure 1). The Wadi originates in the hill slope of EL-Tih plateau. The main trunk of the Wadi extends roughly in a NE-SW direction for about $55 \mathrm{~km}$ and flows into the Suez Gulf at Ras Sudr (c. $55 \mathrm{~km}$ south of El-Shatt) (Girgis \& Ahmed, 1985).

According to Helmy et al. (1996) and Moustafa \& Abdel Wahab (2013) the amount of annual rainfall in $\mathrm{W}$. Sudr was $18.7 \mathrm{~mm}$, while the highest temperature was recorded in July $35.5^{\circ} \mathrm{C}$ and the lowest temperature recorded in March $8.3^{\circ} \mathrm{C}$.

\section{Material and methods}

\section{Vegetation sampling procedures}

The field studies of the present work conducted through regular visits during two successive years 2012 and 2013. The selection of stands was depending on the change in the vegetation structure and composition along Wadi Sudr. The study included 21 geo-referenced stands using GPS device (Garmin etrex). Each stand was vegetationally analyzed by using quadrate methods, each stand contained 5 quadrates $(10 \times 10 \mathrm{~m})$ that were randomly positioned along the Wadi. The species in each stand were listed and the number of individuals of each species was counted and used in the estimation of its absolute and relative densities. The number of occurrences of a species in quadrates of each stand was used to calculate its absolute and relative frequencies. The coverage of a species was estimated by using the line-intercept method. The relative values of density, frequency and cover for each species were summed up to give its importance value (IV) out of 300 (Curtis \& McIntosh, 1950; Ludwig \& Reynolds, 1988).

The phytogeographical (chorology) analysis of the recorded plant species were based on Zohary (1966 \& 1972), Feinbrun-Dothan (1978 \& 1986), Danin (2006). The recorded species were classified according Raunkiaer's life-form classification system (Raunkiaer, 1934). The taxonomical nomenclature of the plant species was after Täckholm (1974), Boulos (1999, 2000, 2002, 2005 and 2009).

\section{Soil sampling and analysis}

Soil samples were collected from the subsurface layer $(20-40 \mathrm{~cm})$, airdried, and kept for determination of soil texture (Krumbein \& Sloss, 1963 and Ryan et al., 1996), $\mathrm{pH}$ was measured by using a portable $\mathrm{pH}-$ meter (Model, Orion 2 star), electrical conductivity was measured by using a portable conductivity meter (Model, Orion 3 star) (Richards, 1954), Chlorides were estimated by titration methods (Jackson, 1967), 
Sulphates were estimated by the turbidimetric method (Standard methods, 1989) and measured by spectrophotometer (Model, Spectronic 20 D). Sodium and potassium by using flame photometer (JENWAY PEP 7), $\mathrm{HCO}_{3}{ }^{-}, \mathrm{Ca}^{2+}$ and $\mathrm{Mg}^{2+}$ were estimated by titration methods (Richards, 1954 and Ryan et al., 1996). Calcium carbonate was determined volumetrically using Collin's Calcimeter (Piper, 1950).

\section{Multivariate analysis procedures}

In the present study, two trends of multivariate analysis were applied on the collected data: Two Way Indicator Species Analysis (TWINSPAN) (Hill, 1979; Gauch \& Whittaker, 1981) was used for classification of samples stands into definite vegetation groups and Canonical Correspondence Analysis (CCA) (TerBraak \& Prentice, 1988) was used for ordination. The input data in both techniques were in two forms: stands versus species important values (I.V.) data matrix ( 21 stands $\times 46$ species) and stands versus environmental factors data matrix (21 stands $\times 18$ soil parameters) respectively. TWINSPAN classification was carried out by using a computer program (CAP, Community Analysis Package, version 1.3.1, Henderson \& Seaby, 1999). CCA was performed by using CANOCO for windows program, version 4.5.2., (TerBraak \& Smilauer 2002) and PCORD Software version 4.37 (McCune \& Mefford, 2005).

\section{Biodiversity indices}

Four biodiversity indices were calculated for the different vegetation groups identified by the TWINSPAN numerical classification technique according to (Pielou, 1975); (Ludwig \& Reynolds, 1988) and (Magurran, 2004), these indices are described as follows:

Species richness ( $\alpha$-diversity) for each vegetation group was calculated as the average number of species per stand, and Species turnover $(\beta$ diversity) as the ratio between the total number of species recorded in a certain vegetation group and its alpha diversity (Whittaker, 1972 and Wilson \& Shmida, 1984). Relative equitability or evenness of the importance value of species was expressed according to Shannon diversity index ( $\left.\mathrm{H}^{\prime}\right)$ (Perkins, 1982). Meanwhile, the heterogeneity dominance measure was expressed by the Simpson index (D). All the computations were done by using a computer program (Biodiversity Professional, Version 2.0, McAleece et al., 1997). 


\section{Results}

\section{Floristic analysis}

a. Floristic list

Floristic composition is a function of the relation between plants and their habitat. A complete list of scientific names and families of the recorded species in the study area was represented in Table (1). The total number of the recorded plant species in the study area were 54 species (46 perennials and 8 annuals) belonging to 44 genera and representing 22 families. These families were distributed as 2 monocotyledons and 20 dicotyledons. The abundant families in Wadi Sudr were Zygophyllaceae (15\%), Astraceae and Leguminosae (each 11\%).

\section{b. Life form}

According to life form classification scheme by Raunkiaer (1934), the recorded species in the recent study were grouped in the four major life form classes' namely Chamaephytes (57.41\%), Phanerophytes (18.51\%), Therophytes (14.82\%) and Hemicryptophytes (9.26\%) showed in Figure (1). Chamaephytes were the dominant life forms in the studied Wadi.

\section{c. Chorotype}

Considering the global floristic regions, analysis of the recorded plant species in the study area was listed in Table (2), three major categories were observed $71 \%$ of the species were monoregional, $21 \%$ were bioregional and $8 \%$ were pluriregional. Monoregional Saharo-Arabian chorotype is shown in a higher percentage (47\%) than the inter-regional chorotypes ( $\mathrm{Bi}$ and pluriregionals).

\section{Multivariate analysis}

\subsection{Classification}

The dendrogram resulting from the application of TWINSPAN classification based on the importance values of 54 species recorded in 21 stands indicated the distinction of five vegetation groups (Figure 3 ). The characterizations of the vegetation groups of the Wadi were presented in Table ( 3 \& 4). Each group comprised a set of stands with greater homogeneity of vegetation.

Group I. This group consisted of two stands and nine species and occupied the downstream portion of W. Sudr. The leading dominant species of this group was Zygophyllum album, while the co-dominant species were Nitraria retusa, Arthrocnemon glaucum and Halocnemum strobilaceum. The mean soil parameters in this group showed the highest values of E.C., $\mathrm{Na}^{+}, \mathrm{K}^{+}, \mathrm{Ca}^{2+}, \mathrm{Mg}^{2+}, \mathrm{HCO}_{3}^{-}, \mathrm{Cl}^{-}, \mathrm{SO}_{4}{ }^{2-}$, very fine sand and silt and clay, 
and the lowest value of very fine gravil, very course sand and course sand. Regarding relative evenness (Shannon index) and relative concentration of dominance (Simpson index), vegetation group I recorded the highest value for Shannon index and the lowest value for Simpson index and species turn over.

Group II. It comprised five stands and twenty-one species and occupied the upstream of Wadi Sudr which was characterized by the presence of many depressed areas. The leading dominant species of this group was Retama raetam, while the co-dominant species included Reaumuria hirtella, Tamarix nilotica, Zygophyllum aegyptium and Z. dumosum. The mean soil parameters in this group showed a high mean value of $\mathrm{CaCO}_{3} \%$ and medium sand.

Group III. It comprised six stands and twenty-five species and included Sudr well (Ain Sudr) which is the most important water point in this area, and Wadi El-Melehy one of the upstream tributaries of W. Sudr. The leading dominant species of this group was Reaumuria hirtella, while the co-dominant species included Haloxylon salicornicum, Retama raetam, Moricandia nitens and Zygophyllum dumosum. The mean soil parameters in this group showed the highest mean value of fine sand, while it showed the lowest value of $\mathrm{CO}_{3}{ }^{-2}$.The highest value for species turnover was recorded in this vegetation group, while it recorded the lowest value for species richness and Simpson index.

Group IV. It embraced five stands and thirty species and occupied the up and mid stream of Wadi Sudr. The dominant species was Retama raetam, while the co-dominant species were Haloxylon salicornicum and Achillea fragrantissima. The highest mean values of $\mathrm{CO}_{3}^{-2}$ and coarse sand were recorded in soil supporting group III, and also the lowest mean values of $\mathrm{EC}, \mathrm{Na}^{+}, \mathrm{Ca}^{+2}, \mathrm{Mg}^{-}, \mathrm{HCO}_{3}^{-}, \mathrm{SO}_{4}^{-2}, \mathrm{CaCO}_{3}$, fine sand, and very fine sand and silt and clay. This vegetation group attained the highest value for species richness and Shannon index. This group was characterized by the formation of sand hummocks in the midstream part of the Wadi. H. salicornicum \& Tamarix aphylla inhibited this habitat, growing in distantly spaced patches from hummocks.

Group V. It comprised three stands and fifteen species and occupied the midstream portion of the Wadi. The leading dominant species of this group was Haloxylon salicornicum. The co-dominant species comprised Retama raetam, Reaumuria hirtella and Zygophyllum dumosum. The mean soil parameters in this group showed the highest value of very fine gravel and 
very coarse sand. While it showed the lowest $\mathrm{K}^{+}, \mathrm{Cl}^{-}$value and medium sand.

\subsection{Ordination}

The relations between vegetation structure along the studied Wadi and environmental variables were examined by using CCA ordination program. This program produces two different biplots. The first biplot reflects the relationships between the different vegetational groups as previously identified by TWINSPAN classification program and the environmental factors, while the second biplot reveals the relationships between the recorded species along the Wadi and the environmental factors.

a. Biplot of the vegetational groups Figure (4a) show that group I representing the downstream which was affected by anions, cations, $\mathrm{pH}$, EC and very fine soil texture $(<0.125 \mathrm{~mm})$. However, the larger soil particles $(>0.125 \mathrm{~mm})$ were the most effective factors on group II, III and V. On the other hand $\mathrm{CaCO}_{3}$ was the effecting factor on group IV.

b. Biplot of the species Figure (4b) revealed that halophytes like Limonium pruinosum, Halocnemum strobilaceum, Arthrocnemon macrostachyum, Tamarix nilotica, Nitraria retusa and Zygophyllum album were associated with more than one chemical environmental variable in addition to very fine sand and silt \& clay, while several species showed close association with $\mathrm{CaCO}_{3}$ and fine sand eg. Deverra tortusa, Fagonia mollis, Gymnocarpos decandrus, Centaurea aegyptiaca and Echinops spinosus. On the other hand soil texture from very fine gravel to medium sand fractions affected species such as Haloxylon salicornicum, Retama raetam, Farsetia aegyptia, Ochradenus baccatus, Reaumuria hirtella, Achillea fragrantissima and Zygophyllum coccineum.

\section{Discussion}

Floristic analysis of Wadi Sudr revealed that the total number of the recorded plant species were 54 species, and the abundant families were Zygophyllaceae, Astraceae and Leguminosae. This agreed with Moustafa (1990), Abd-El Ghani \& Amer (2003) and Ali (2004) who mentioned that the flora of South Sinai is characterized by the dominance of families: Astraceae, Zygophyllacae, Leguminosae, Chenopodiaceae and Labiatae. Girgis \& Ahmed (1985) in their survey of W. Sudr recorded about 55 species most of them listed in this study indicating no remarkable change in the floristic composition of the Wadi. Considering life forms Chamaephytes were the dominant life forms in the studied Wadi. This agreed with Ali 
(2004) and Abu-Taha (2010) who mentioned that the habitats of some Wadis in Sinai were dominated by Chamaephytes. Chorological analysis of the floristic data revealed that the monoregional Saharo-Arabian chorotype was shown in a higher percentage (47\%) than the inter-regional chorotypes (Bi and pluriregionals). Our results were in line with Danin (1983), Hassan (1987) and Ali (2004). Phytogeographically, the Saharo-Arabian element forms the major component of the floristic structure because the study area lies within the Saharo-Arabian region. In contrast, the monoregional IranoTuranian element is poorly represented. This may be attributed to the fact that plants of the Saharo-Arabian region are good indicators for desert environmental conditions (Salama et al., 2014).

The dendrogram resulted from the application of TWINSPAN led to recognition of five vegetation groups one represented the downstream (Group I) while the other four represented the up and midstream of Wadi Sudr (Group II-V). The results of CCA analysis showed the relative positions of species and sites along the most important edaphic factors. Halophytic species in the downstream were affected by chemical soil properties and very fine soil texture. While the larger soil particles and $\mathrm{CaCO}_{3}$ were the most effective factors on the distribution of xerophytes in the up and midstream of Wadi Sudr.

Group I was dominated by halophytic species Zygophyllum album, Arthrocnemon glaucum, Halocnemum strobilaceum and Tamarix nilotica. This group showed the highest values of E.C., mineral contents and fine soil texture which was also reported by Migahid et al., (1996) who stated that the soil supporting the growth of A. macrostachyum \& Z. album was characterized by high contents of sand, salinity, chlorides, sodium, and sulfates. According to Zahran (1967) the zone of littoral salt marshes is subjected to inundation during high tide, lateral extension of the sea water underground and sea spray. Tamarix had been identified as a major cause of salt accumulation on the soil surface (Springuel \& Ali, 1990). In addition, there is a relationship between the amount of Tamarix litter and soil E.C. (Briggs et al., 1993). Meanwhile, the lower number of recorded species in this group (9 species) may be related to its high soil salinity. Such salinity stress on floristic diversity in related areas was reported by Moustafa \& Klopatek (1995), Shaltout et al., (1997) and Salama et al., (2014).

Vast areas in the Egyptian deserts (Western, Eastern, and Sinai) were subjected to land reclamation due to increased population growth (Biswas, 1993). Girgis \& Ahmed (1985) stated that the vegetation of downstream of 
the main channel of W. Sudr was an open forest dominated by Tamarix aphylla with frequent $T$. nilotica. Due to the extensive human activities represented in cultivated farms, land reclamation, buildings along the coast shore of Ras Sudr extending to the whole downstream of the Wadi, there was a noticeable change in the vegetation and a decrease in the number of species affected the plant population especially the Tamarix forest. Similar conclution was obtained by Salama et al., (2014) who noticed change in the deltic parts of several Wadis such as Wadi Kherit, W. Natash and W. ElShikh due to agricultural processes.

The groups represented the up and midstream of Wadi Sudr were dominated by Retama raetam and Haloxylon salicornicum. In this context Girgis \& Ahmed (1985) reported seven basic communities as most abundant communities in the Wadis of South-West Sinai, such as Retama raetam, Haloxylon salicornicum, Tamarix nilotica and Acacia raddiana. Soil supporting $H$. salicornicum community was the course sandy texture that might be intermixed with gravel.

The midstream was characterized by the formation of sand hummocks with low values of E.C, mineral contents and $\mathrm{CaCO}_{3}$. Haloxylon salicornicum inhibited this habitat, growing in distantly spaced patches form hummocks by which the plant was able to overcome the fluctuation of rainfall and drought (Ali, 2004). Tamarix aphylla also formed hillocks of huge sizes, representing the natural climax community type of the desert Wadis with deep deposits and an underground water reserve (Kassas \& Zahran, 1965). The low mean values of silt \& clay, E.C. and $\mathrm{Na}^{+}$agreed with the findings of Abu-Taha (2010) in soil supporting hummocks of Wadi El-Fath at El-Maghara area, Sinai.

Ain Sudr exists in the flood channel of the main tributary of W. Sudr, supporting a vigor growth of many species such as Reaumuria hirtella, Peganum harmala, Cressa cretica, Solanum negrum and Zilla spinosa. On the western slope following Ain Sudr, dense groves of the semi-wild Phoenix dactylifera (date palm) were recorded. The presence of palm had been an indicator of a fresh-water zone among the underground water layers (Abdel Rahman et al., 1965). Girgis \& Ahmed (1985) and Marie (1988) recorded oasis type of vegetation surrounding Ain Sudr. The same habitat was also studied by Zahran \& Willis (2009) and Shawky (2010). Capparis sainica and C. spinosa were recorded in the fractures of the rocky sides of the upstream of the Wadi. This was also reported by Girgis \& Ahmed (1985) and Zahran \& Willis (2009) who stated that C. sainica is 
occasionally growing in the crevices and fractures of the cliffs and the rocky sides of Wadi Sudr. Girgis \& Ahmed (1985) also mentioned that the vegetation of the big affluent draining gravel formation was a Pancium turgidum grassland and this species was subjected to extensive overgrazing which led to the disappearance of the grassland in the present study.

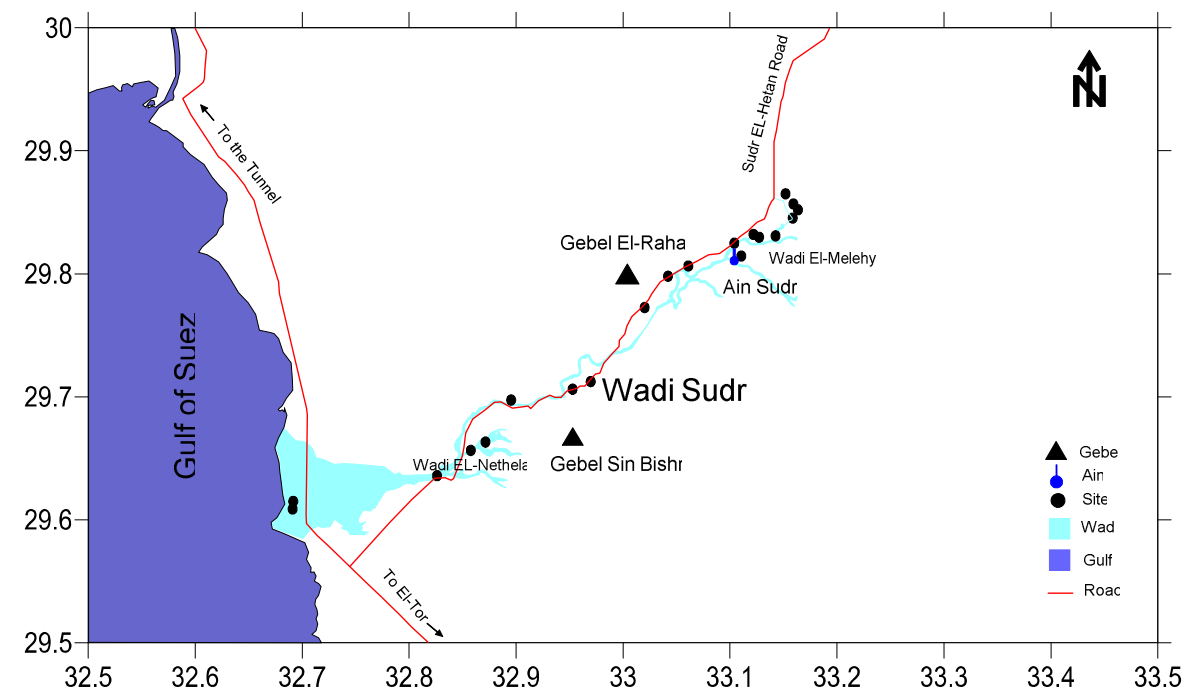

Figure 1. Location map of Wadi Sudr.

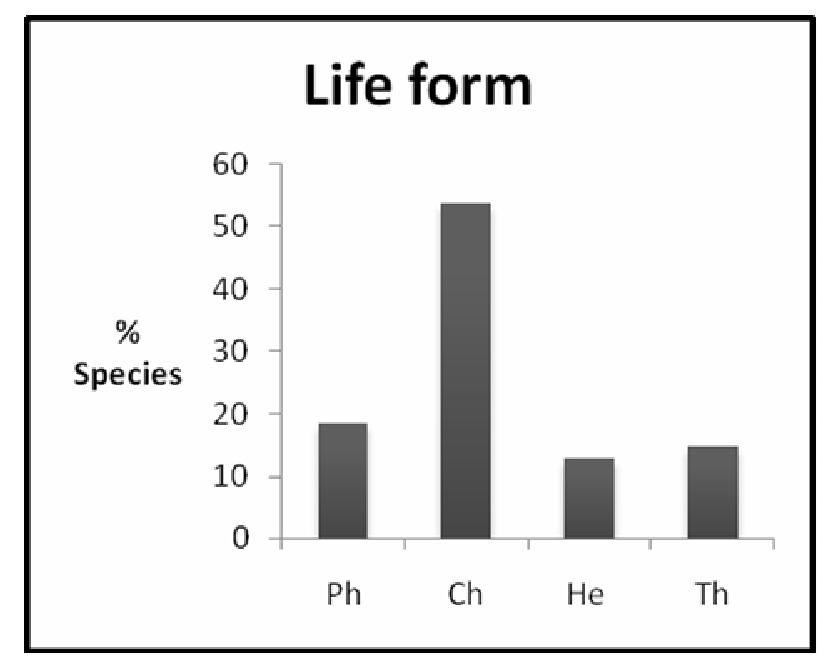

Figure 2. Proportional percentage of life forms of the recorded species in Wadi Sudr. $\mathrm{Ch}=$ Chamaephytes, $\mathrm{Ph}=$ Phanerophytes, $\mathrm{He}=$ Hemicryptophytes and $\mathrm{Th}=$ Therophytes. 


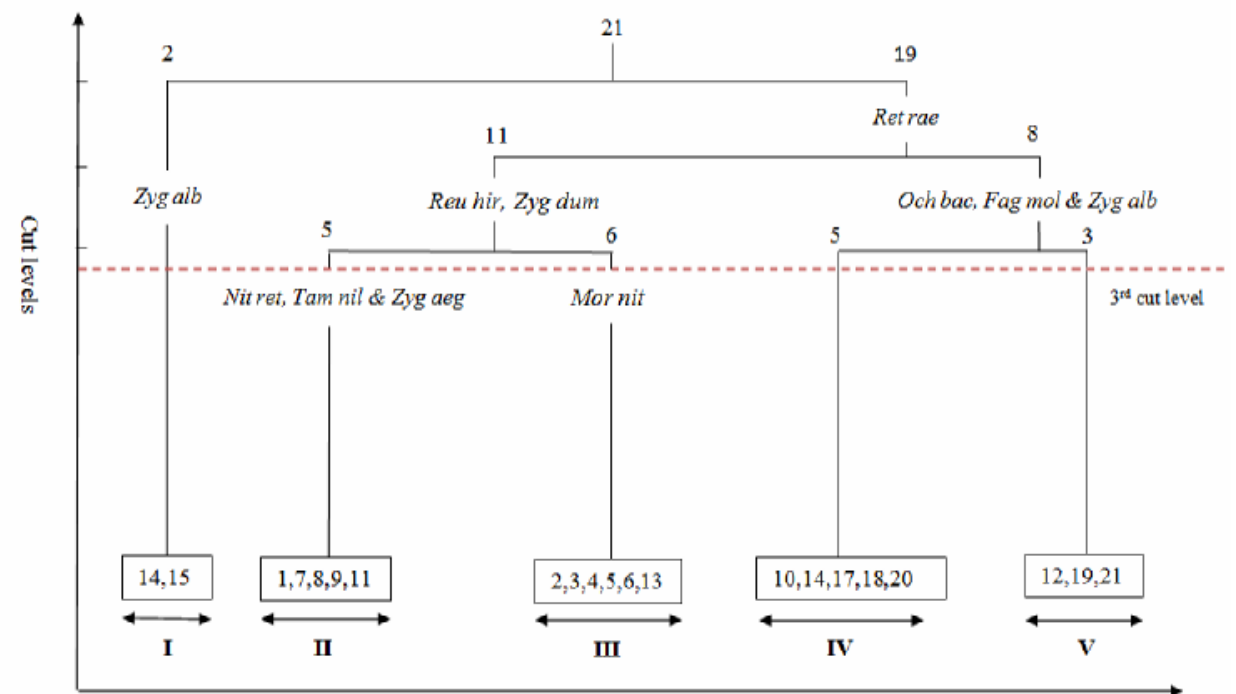

Figure 3. TWINSPAN dendrogram of 21 stands based on the Importance value (I.V.), the third iteration cycle considered as a satisfactory cut level, species names were abbreviated to the first three letters of genus and species names respectively. For full species names see Table (1).

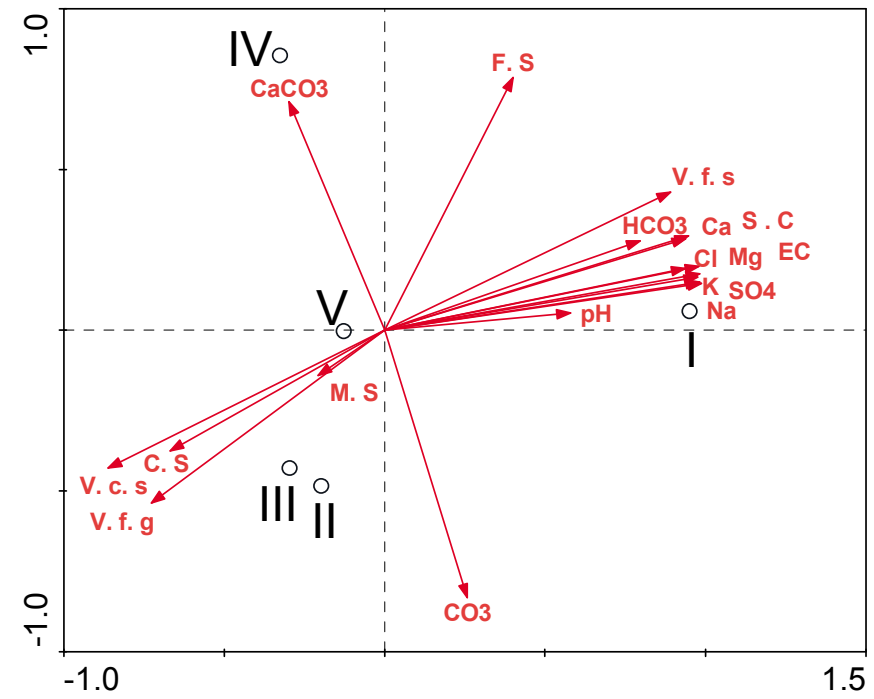

Figure 4a. Canonical Correspondence Analysis (CCA) ordination diagram showing the relationships between the five vegetation groups represented by circles and 18 edaphic variables represented by arrows in Wadi Sudr. For full name of edaphic factors see Table (3). 


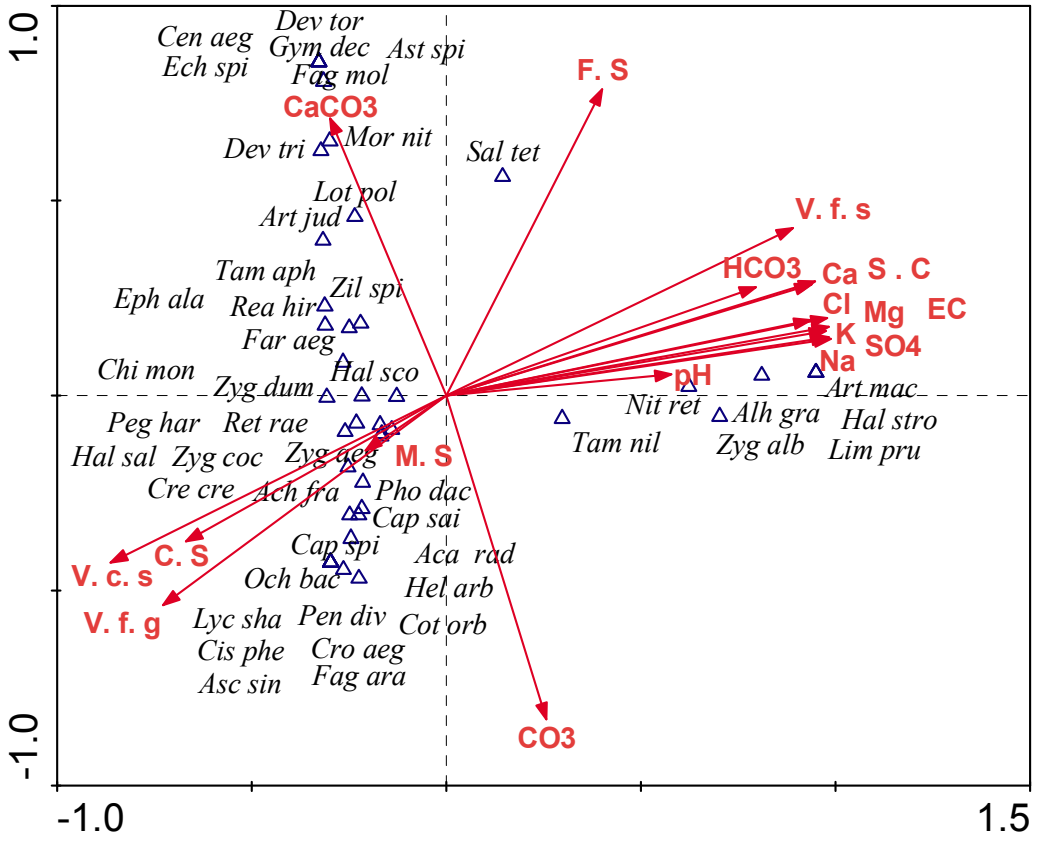

Figure 4b. Canonical Correspondence Analysis (CCA) showing the relationships of the recorded species and the soil parameters in Wadi Sudr. Species names are abbreviated to the first three letters of genus and species names respectively. For full species names see Table (1).

Table 1. List of the recorded families with their species in Wadi Sudr.

\begin{tabular}{|c|l|}
\hline Family & \multicolumn{1}{|c|}{ Species } \\
\hline Apiaceae & $\begin{array}{l}\text { Deverra tortuosa } \text { (Desf.) DC. } \\
\text { D. triradiata } \text { Hochst. }\end{array}$ \\
\hline Asclepiadaceae & Asclepias sinaica (Boiss.) Muschl. \\
\hline \multirow{3}{*}{ Astreaceae } & Achillea fragrantissima (Forssk.) Sch.Bip. \\
& Artemisia judaica L. \\
& Chiliadenus montanus (Vahl) Brullo \\
& Centaurea aegyptiaca L. \\
& Echinops spinosus L. \\
& Pulicaria incisa (Lam.) DC. \\
\hline Boraginaceae & Heliotropium arbainense Fresen. \\
\hline Capparaceae & Capparis sinaica Veill. \\
\hline Caryophyllaceae & C. spinosa L. \\
\hline & Gymnocarpos decandrus Forssk. \\
\hline
\end{tabular}




\begin{tabular}{|c|c|}
\hline Chenopodiaceae & $\begin{array}{l}\text { Arthrocnemun macrostachyum (Moric.) } \\
\text { Halocnemum strobilaceum (Pall.) M. Bieb. } \\
\text { Haloxylon salicornicum (Moq.) Bunge ex Boiss. } \\
\text { H. scoparium Pomel } \\
\text { Salsola tetrandra Forssk. }\end{array}$ \\
\hline Cleomaceae & Cleome amblyocarpa Barratte \& Murb. \\
\hline Convolvulaceae & Cressa cretica L. \\
\hline Cruciferae & $\begin{array}{l}\text { Diplotaxis harra (Forssk.) Boiss. } \\
\text { Farsetia aegyptia Turra } \\
\text { Matthiola longipetala (Vent.) DC. } \\
\text { Morcandia nitens (Viv.) Durand \& Barratte } \\
\text { Zilla spinosa (Turra) Prantl }\end{array}$ \\
\hline Ephedraceae & Ephedra alata Decne. \\
\hline Family & Species \\
\hline Gramineae & Pennisetum divisum (Forssk. ex J. F. Gmel.) Henrard \\
\hline Leguminosae & $\begin{array}{l}\text { Acacia tortilis (Forssk.) Hayne subsp. raddiana (Savi) Brenan } \\
\text { Alhagi graecorum Boiss. } \\
\text { Astragalus spinosus (Forssk.) Muschl. } \\
\text { Crotalaria aegyptiaca Benth. } \\
\text { Lotus sp. } \\
\text { Retama raetam (Forssk.) Webb \& Berthel }\end{array}$ \\
\hline Nitrariaceae & Nitraria retusa (Forssk.) Asch \\
\hline Orbanchaceae & Cistanche phelypaea L. Cout \\
\hline Arecaceae & Phoenix dactylifera $\mathrm{L}$. \\
\hline Plumbaginaceae & Limonium pruinosum (L.) Chaz. \\
\hline Resedaceae & $\begin{array}{l}\text { Ochradenus baccatus Delile. } \\
\text { Reseda alba } \text { L. } \\
\text { R. pruinosa } \text { Delile. }\end{array}$ \\
\hline Rosaceae & Cotoneaster orbicularis Schltdl. \\
\hline Solanaceae & $\begin{array}{l}\text { Solanum nigrum } \mathrm{L} . \\
\text { Lycium shawii Roem. \& Schult. }\end{array}$ \\
\hline Tamaricaceae & $\begin{array}{l}\text { Reaumuria hirtella Jaub \& Spach } \\
\text { Tamarix aphylla (L.) H. Karst. } \\
\text { T. nilotica (Ehrenb.) Bunge }\end{array}$ \\
\hline Zygophyllaceae & $\begin{array}{l}\text { Fagonia arabica } \mathrm{L} . \\
\text { F. mollis Delile } \\
\text { Peganum harmala } \mathrm{L} . \\
\text { Zygophyllum aegyptium A. Hosny } \\
\text { Z. album } \mathrm{L} \mathrm{f.} \\
\text { Z. coccineum } \mathrm{L} \text {. } \\
\text { Z. dumosum Boiss. } \\
\text { Z. simplex } \mathrm{L} \text {. }\end{array}$ \\
\hline
\end{tabular}


Table 2. Chorological analysis of the recorded species as numbers and percentages of the species recorded in Wadi Sudr.

\begin{tabular}{|c|c|c|}
\hline Phytochoria & No. of Species & \% of Species \\
\hline I- Monoregional & & \\
Sudanian & 8 & 14.82 \\
Saharo-Arabian & 26 & 48.15 \\
Mediterranean & 3 & 6.56 \\
Irano-Turanian & 1 & 1.85 \\
Total & $\mathbf{3 8}$ & $\mathbf{7 1 \%}$ \\
\hline II- Biregional & 4 & 7.41 \\
Mediterranean + Irano-Turanian & 2 & 3.7 \\
Saharo-Arabian + Mediterranean & 3 & 5.56 \\
Saharo-Arabian + Irano-Turanian & 3 & 5.56 \\
Saharo-Arabian + Sudanian & $\mathbf{1 2}$ & $\mathbf{2 2 \%}$ \\
Total & 3 & 5.56 \\
\hline III- Pluriregional & 1 & 1.85 \\
Mediterranean + Irano-Turanian + Saharo-Arabian & $\mathbf{4} \%$ \\
\hline Euro-Siberian + Mediterranean + Irano-Turanian & $\mathbf{4}$ & $\mathbf{1 0 0}$ \\
\hline Total & $\mathbf{5 4}$ & \\
\hline Total of all species & & \\
\hline
\end{tabular}

Table 3. Mean and standard deviation values of the soil variables in the five vegetation groups obtained by TWINSPAN.

\begin{tabular}{|c|c|c|c|c|c|}
\hline No. of group & I & II & III & IV & $\mathrm{V}$ \\
\hline No. of stands & 2 & 3 & 5 & 6 & 5 \\
\hline No. of species & 9 & 15 & 30 & 25 & 21 \\
\hline \multicolumn{6}{|c|}{ Soil parameters } \\
\hline pH & $\begin{array}{c}8.32 \\
\pm 0.25\end{array}$ & $\begin{array}{c}7.60 \\
\pm 0.21\end{array}$ & $\begin{array}{c}8.22 \\
\pm 0.38\end{array}$ & $\begin{array}{c}7.90 \\
\pm 0.27\end{array}$ & $\begin{array}{c}7.99 \\
\pm 0.48\end{array}$ \\
\hline EC mmohs $\mathrm{cm}^{-1}$ & $\begin{array}{l}10.53 \\
\pm 2.19 \\
\end{array}$ & $\begin{array}{c}1.60 \\
\pm 0.56 \\
\end{array}$ & $\begin{array}{c}0.64 \\
\pm 0.52 \\
\end{array}$ & $\begin{array}{c}4.49 \\
\pm 1.08 \\
\end{array}$ & $\begin{array}{c}2.41 \\
\pm 1.44 \\
\end{array}$ \\
\hline $\mathrm{Na}^{+} \operatorname{meq~} \mathbf{L}^{-1}$ & $\begin{array}{r}94.40 \\
\pm 35.09\end{array}$ & $\begin{array}{c}3.27 \\
\pm 0.34\end{array}$ & $\begin{array}{c}1.85 \\
\pm 1.28 \\
\end{array}$ & $\begin{array}{l}10.60 \\
\pm 9.05\end{array}$ & $\begin{array}{l}13.17 \\
\pm 9.58 \\
\end{array}$ \\
\hline $\mathbf{K}^{+} \operatorname{meq} \mathbf{L}^{-1}$ & $\begin{array}{c}1.77 \\
\pm 1.17\end{array}$ & $\begin{array}{c}0.27 \\
\pm 0.04\end{array}$ & $\begin{array}{c}0.32 \\
\pm 0.48\end{array}$ & $\begin{array}{c}0.43 \\
\pm 0.32\end{array}$ & $\begin{array}{c}0.40 \\
\pm 0.22\end{array}$ \\
\hline $\mathrm{Ca}^{+2}$ meq $\mathrm{L}^{-1}$ & $\begin{array}{c}20.11 \\
\pm 14.53 \\
\end{array}$ & $\begin{array}{c}6.95 \\
\pm 2.37 \\
\end{array}$ & $\begin{array}{c}2.46 \\
\pm 2.78 \\
\end{array}$ & $\begin{array}{c}8.51 \\
\pm 2.75 \\
\end{array}$ & $\begin{array}{c}7.18 \\
\pm 4.69 \\
\end{array}$ \\
\hline $\mathrm{Mg}^{+} \operatorname{meq} \mathbf{L}^{-1}$ & $\begin{array}{l}13.91 \\
\pm 7.20 \\
\end{array}$ & $\begin{array}{c}5.46 \\
\pm 3.91 \\
\end{array}$ & $\begin{array}{c}1.81 \\
\pm 1.18 \\
\end{array}$ & $\begin{array}{c}5.31 \\
\pm 2.20 \\
\end{array}$ & $\begin{array}{r}3.33 \\
\pm 2.09 \\
\end{array}$ \\
\hline $\mathrm{CO}_{3}^{-2}$ meq $\mathrm{L}^{-1}$ & $\begin{array}{c}0.33 \\
\pm 0.47\end{array}$ & $\begin{array}{c}0.39 \\
\pm 0.40\end{array}$ & $\begin{array}{c}0.41 \\
\pm 0.92\end{array}$ & $\begin{array}{c}0.00 \\
\pm 0.00\end{array}$ & $\begin{array}{c}0.06 \\
\pm 0.14\end{array}$ \\
\hline $\mathrm{HCO}_{3}^{-}$meq $\mathrm{L}^{-1}$ & $\begin{array}{c}1.15 \\
\pm 0.23 \\
\end{array}$ & $\begin{array}{c}0.74 \\
\pm 0.44 \\
\end{array}$ & $\begin{array}{c}0.58 \\
\pm 0.30 \\
\end{array}$ & $\begin{array}{c}0.79 \\
\pm 0.26 \\
\end{array}$ & $\begin{array}{c}1.01 \\
\pm 0.25 \\
\end{array}$ \\
\hline
\end{tabular}




\begin{tabular}{|c|c|c|c|c|c|}
\hline $\mathrm{Cl}^{-} \operatorname{meq} \mathrm{L}^{-1}$ & $\begin{array}{r}65.79 \\
\pm 73.70 \\
\end{array}$ & $\begin{array}{c}2.85 \\
\pm 0.60 \\
\end{array}$ & $\begin{array}{c}2.90 \\
\pm 2.23 \\
\end{array}$ & $\begin{array}{l}10.24 \\
\pm 8.14 \\
\end{array}$ & $\begin{array}{l}13.67 \\
\pm 8.56 \\
\end{array}$ \\
\hline $\mathrm{SO}_{4}^{-2}$ meq $^{-1}$ & $\begin{array}{c}62.92 \\
\pm 45.47\end{array}$ & $\begin{array}{l}11.97 \\
\pm 6.31\end{array}$ & $\begin{array}{c}2.54 \\
\pm 2.22\end{array}$ & $\begin{array}{l}13.81 \\
\pm 5.22\end{array}$ & $\begin{array}{c}9.32 \\
\pm 5.68\end{array}$ \\
\hline $\mathrm{CaCO}_{3} \%$ & $\begin{array}{l}42.75 \\
\pm 2.62 \\
\end{array}$ & $\begin{array}{c}42.67 \\
\pm 11.82 \\
\end{array}$ & $\begin{array}{c}37.84 \\
\pm 13.67\end{array}$ & $\begin{array}{r}64.30 \\
\pm 8.53 \\
\end{array}$ & $\begin{array}{l}66.30 \\
\pm 7.55\end{array}$ \\
\hline Very fine gravel \% & $\begin{array}{r}4.30 \\
\pm 0.83\end{array}$ & $\begin{array}{l}20.08 \\
\pm 9.45\end{array}$ & $\begin{array}{l}14.77 \\
\pm 7.75\end{array}$ & $\begin{array}{r}10.62 \\
\pm 10.91\end{array}$ & $\begin{array}{r}10.62 \\
\pm 12.55\end{array}$ \\
\hline Very coarse sand \% & $\begin{array}{c}6.55 \\
\pm 6.12\end{array}$ & $\begin{array}{l}13.27 \\
\pm 1.22\end{array}$ & $\begin{array}{l}15.10 \\
\pm 5.25\end{array}$ & $\begin{array}{c}11.20 \\
\pm 10.80\end{array}$ & $\begin{array}{r}10.82 \\
\pm 11.23\end{array}$ \\
\hline Coarse sand \% & $\begin{array}{r}7.54 \\
\pm 7.90 \\
\end{array}$ & $\begin{array}{l}10.14 \\
\pm 3.24 \\
\end{array}$ & $\begin{array}{l}15.97 \\
\pm 4.77 \\
\end{array}$ & $\begin{array}{l}10.35 \\
\pm 6.38 \\
\end{array}$ & $\begin{array}{l}11.36 \\
\pm 6.87 \\
\end{array}$ \\
\hline Medium sand \% & $\begin{array}{l}12.97 \\
\pm 6.07\end{array}$ & $\begin{array}{l}10.77 \\
\pm 3.08\end{array}$ & $\begin{array}{l}17.31 \\
\pm 6.76\end{array}$ & $\begin{array}{c}12.72 \\
\pm 6.20\end{array}$ & $\begin{array}{c}18.84 \\
\pm 10.36\end{array}$ \\
\hline Fine sand \% & $\begin{array}{c}25.79 \\
\pm 15.41\end{array}$ & $\begin{array}{l}22.86 \\
\pm 8.87\end{array}$ & $\begin{array}{l}18.82 \\
\pm 8.29\end{array}$ & $\begin{array}{c}26.70 \\
\pm 12.72\end{array}$ & $\begin{array}{r}23.51 \\
\pm 13.73\end{array}$ \\
\hline Very fine sand \% & $\begin{array}{l}29.81 \\
\pm 6.31 \\
\end{array}$ & $\begin{array}{l}15.08 \\
\pm 3.73 \\
\end{array}$ & $\begin{array}{l}11.45 \\
\pm 9.43 \\
\end{array}$ & $\begin{array}{c}19.77 \\
\pm 16.62 \\
\end{array}$ & $\begin{array}{r}16.68 \\
\pm 15.85 \\
\end{array}$ \\
\hline Silt \& Clay \% & $\begin{array}{l}13.06 \\
\pm 2.47\end{array}$ & $\begin{array}{c}7.81 \\
\pm 2.17\end{array}$ & $\begin{array}{c}6.58 \\
\pm 5.66\end{array}$ & $\begin{array}{c}8.65 \\
\pm 11.78\end{array}$ & $\begin{array}{c}8.17 \\
\pm 12.33\end{array}$ \\
\hline
\end{tabular}

Table 4. Importance value Means and standard deviations $( \pm$ ) for species characterizing the five vegetation groups distinguished by TWINSPAN program in Wadi Sudr.

\begin{tabular}{|c|c|c|c|c|c|}
\hline No. of group & I & II & III & IV & $\mathrm{V}$ \\
\hline No. of stands & 2 & 3 & 5 & 6 & 5 \\
\hline No. of species & 9 & 15 & 30 & 25 & 21 \\
\hline $\begin{array}{l}\text { Acacia tortilis (Forssk.) Hayne subsp. } \\
\text { raddiana (Savi) Brenan }\end{array}$ & - & - & $\begin{array}{r}9.19 \\
\pm 12.60\end{array}$ & - & $\begin{aligned} & 3.7 \\
\pm & 5.83\end{aligned}$ \\
\hline $\begin{array}{l}\text { Achillea fragrantissima (Forssk.) Sch. } \\
\text { Bip. }\end{array}$ & - & $\begin{array}{r}7.75 \\
\pm 1.42\end{array}$ & $\begin{array}{c}31.75 \\
\pm 34.60\end{array}$ & $\begin{array}{r}7.56 \\
\pm 18.52\end{array}$ & $\begin{array}{r}12.42 \\
\pm 13.50\end{array}$ \\
\hline Alhagi graecorum Boiss. & $\begin{array}{c}31.21 \\
\pm 44.14\end{array}$ & - & - & - & $\begin{array}{r}4.65 \\
\pm 10.40\end{array}$ \\
\hline Artemisia judaica $\mathrm{L}$. & - & - & $\begin{array}{c}7.03 \\
\pm 7.54\end{array}$ & $\begin{array}{r}12.69 \\
\pm 20.85\end{array}$ & - \\
\hline Arthrocnemun macrostachyum (Moric.) & $\begin{array}{c}50.09 \\
\pm 70.84\end{array}$ & - & - & - & - \\
\hline Asclepias sinaica (Boiss.) Muschl. & - & $\begin{array}{c}22.37 \\
\pm 28.23\end{array}$ & $\begin{array}{r}1.89 \\
\pm 4.23\end{array}$ & - & - \\
\hline Astragalus spinosus (Forssk.) Muschl. & - & $\begin{array}{c}22.8 \\
5 \pm 13.12 \\
\end{array}$ & - & $\begin{array}{r}0.98 \\
\pm 2.40 \\
\end{array}$ & - \\
\hline Capparis sinaica Veill. & - & - & $\begin{array}{r}9.35 \\
\pm 9.37 \\
\end{array}$ & $\begin{array}{c}3.31 \\
\pm 8.10 \\
\end{array}$ & $\begin{array}{c}4.22 \\
\pm 9.44 \\
\end{array}$ \\
\hline C. spinosa $\mathrm{L}$. & - & - & - & $\begin{array}{c}3.86 \\
\pm 9.46\end{array}$ & - \\
\hline Centaurea aegyptiaca $\mathrm{L}$. & - & - & - & $\begin{array}{c}2.55 \\
\pm 6.24\end{array}$ & - \\
\hline Chiliadenus montanus (Vahl) Brullo & - & - & $\begin{array}{c}7.22 \\
\pm 6.65\end{array}$ & $\begin{array}{c}3.56 \\
\pm 8.71\end{array}$ & - \\
\hline Cistanche phelypaea L. Cout & - & - & $\begin{array}{c}1.31 \\
\pm 2.94\end{array}$ & - & - \\
\hline Cotoneaster orbicularis Schltdl. & - & - & $\begin{array}{c}1.37 \\
\pm 3.06 \\
\end{array}$ & - & - \\
\hline
\end{tabular}


Amal A. Morsy et al.

\begin{tabular}{|c|c|c|c|c|c|}
\hline Cressa cretica $\mathrm{L}$. & - & - & $\begin{array}{c}2.00 \\
\pm 4.47 \\
\end{array}$ & - & $\begin{array}{c}6.92 \\
\pm 15.48 \\
\end{array}$ \\
\hline Crotalaria aegyptiaca Benth. & - & - & $\begin{array}{c}12.92 \\
\pm 20.58 \\
\end{array}$ & - & - \\
\hline Deverra tortuosa (Desf.) DC. & - & - & - & $\begin{array}{c}2.13 \\
\pm 5.22\end{array}$ & - \\
\hline D. triradiata Hochst. & - & - & $\begin{array}{c}1.75 \\
\pm 3.91 \\
\end{array}$ & $\begin{array}{r}8.13 \\
\pm 10.82 \\
\end{array}$ & - \\
\hline Echinops spinosus L. & - & - & - & $\begin{array}{c}0.81 \\
\pm 1.99\end{array}$ & - \\
\hline Ephedra alata Decne. & - & - & $\begin{array}{c}6.48 \\
\pm 14.49 \\
\end{array}$ & $\begin{array}{c}5.84 \\
\pm 14.31 \\
\end{array}$ & - \\
\hline Fagonia arabica $\mathbf{L}$. & - & $\begin{array}{c}14.36 \\
\pm 13.10 \\
\end{array}$ & $\begin{array}{c}5.24 \\
\pm 7.52 \\
\end{array}$ & - & - \\
\hline F. mollis Delile & - & - & - & $\begin{array}{c}17.91 \\
\pm 14.60\end{array}$ & $\begin{array}{c}1.09 \\
\pm 2.45\end{array}$ \\
\hline Farsetia aegyptia Turra & - & - & $\begin{array}{c}1.94 \\
\pm 4.34\end{array}$ & $\begin{array}{c}1.42 \\
\pm 3.49\end{array}$ & $\begin{array}{r}1.09 \\
\pm 2.45\end{array}$ \\
\hline Gymnocarpos decandrus Forssk. & - & - & - & $\begin{array}{c}5.68 \\
\pm 13.91\end{array}$ & - \\
\hline $\begin{array}{l}\begin{array}{l}\text { Halocnemum strobilaceum } \\
\text { Bieb. }\end{array} \\
\end{array}$ & $\begin{array}{c}33.87 \\
\pm 47.89 \\
\end{array}$ & - & - & - & - \\
\hline $\begin{array}{l}\text { Haloxylon salicornicum (Moq.) Bumge } \\
\text { ex Boiss. }\end{array}$ & $\begin{array}{c}10.57 \\
\pm 14.96\end{array}$ & $\begin{array}{c}46.67 \\
\pm 50.68\end{array}$ & $\begin{array}{c}45.52 \\
\pm 26.12\end{array}$ & $\begin{array}{c}34.88 \\
\pm 18.11\end{array}$ & $\begin{array}{c}17.40 \\
\pm 24.34\end{array}$ \\
\hline Haloxylon scoparium Pomel & - & - & - & - & $\begin{array}{c}3.46 \\
\pm 7.74 \\
\end{array}$ \\
\hline Heliotropium arbainense Fresen. & - & - & $\begin{array}{c}4.68 \\
\pm 10.47 \\
\end{array}$ & - & - \\
\hline Limonium pruinosum (L.) Chaz. & $\begin{array}{c}5.49 \\
\pm 7.77\end{array}$ & - & - & - & - \\
\hline Lotus sp. & - & - & - & $\begin{array}{r}1.36 \\
\pm 3.32 \\
\end{array}$ & $\begin{array}{c}1.17 \\
\pm 2.61 \\
\end{array}$ \\
\hline Lycium shawii Roem. \& Schult. & - & $\begin{array}{c}2.67 \\
\pm 4.62 \\
\end{array}$ & $\begin{array}{c}5.43 \\
\pm 7.44 \\
\end{array}$ & - & - \\
\hline $\begin{array}{l}\text { Moricandia nitens (Viv.) Durand \& } \\
\text { Barratte }\end{array}$ & - & - & $\begin{array}{c}2.30 \\
\pm 3.33\end{array}$ & $\begin{array}{c}25.28 \\
\pm 15.68\end{array}$ & $\begin{array}{c}4.04 \\
\pm 3.86\end{array}$ \\
\hline Nitraria retusa (Forssk.) Asch & $\begin{array}{c}57.74 \\
\pm 42.94\end{array}$ & - & $\begin{array}{c}3.37 \\
\pm 7.54\end{array}$ & - & $\begin{array}{c}21.02 \\
\pm 15.08\end{array}$ \\
\hline Ochradenus baccatus Delile. & - & $\begin{array}{c}19.78 \\
\pm 20.97\end{array}$ & $\begin{array}{l}20.40 \\
\pm 5.75\end{array}$ & $\begin{array}{c}2.12 \\
\pm 5.18\end{array}$ & $\begin{array}{c}2.71 \\
\pm 6.05\end{array}$ \\
\hline Peganum harmala $\mathrm{L}$. & - & $\begin{array}{c}1.80 \\
\pm 3.13\end{array}$ & - & - & $\begin{array}{c}8.46 \\
\pm 18.92 \\
\end{array}$ \\
\hline Phoenix dactylifera $\mathrm{L}$. & - & - & $\begin{array}{c}1.07 \\
\pm 2.40\end{array}$ & - & $\begin{array}{c}1.00 \\
\pm 2.23 \\
\end{array}$ \\
\hline $\begin{array}{l}\text { Pennisetum divisum (Forssk. Ex J. F. } \\
\text { Gmel.) Henrard }\end{array}$ & - & - & $\begin{array}{c}1.08 \\
\pm 2.42\end{array}$ & - & - \\
\hline Reaumuria hirtella Jaub \& Spach & - & $\begin{array}{c}24.05 \\
\pm 23.43\end{array}$ & $\begin{array}{c}3.85 \\
\pm 5.43\end{array}$ & $\begin{array}{c}40.12 \\
\pm 20.03\end{array}$ & $\begin{array}{r}44.76 \\
\pm 20.39\end{array}$ \\
\hline $\begin{array}{lllll}\begin{array}{l}\text { Retama } \\
\text { Berthel }\end{array} & \text { raetam } & \text { (Forssk.) Webb \& } & \text { W } \\
\end{array}$ & - & $\begin{array}{l}45.39 \\
\pm 4.91 \\
\end{array}$ & $\begin{array}{c}59.05 \\
\pm 14.51 \\
\end{array}$ & $\begin{array}{c}38.50 \\
\pm 36.25 \\
\end{array}$ & $\begin{array}{c}59.76 \\
\pm 27.79 \\
\end{array}$ \\
\hline Salsola tetrandra Forssk. & $\begin{array}{c}4.68 \\
\pm 6.61\end{array}$ & - & 一 & $\begin{array}{c}7.98 \\
\pm 19.54\end{array}$ & 一 \\
\hline
\end{tabular}




\begin{tabular}{|c|c|c|c|c|c|}
\hline Tamarix aphylla (L.) H. Karst. & - & - & $\begin{array}{c}10.68 \\
\pm 10.70\end{array}$ & $\begin{array}{c}11.22 \\
\pm 27.49\end{array}$ & - \\
\hline T. nilotica (Ehrenb.) Bunge & $\begin{array}{l}26.01 \\
\pm 6.18\end{array}$ & $\begin{array}{l}10.85 \\
\pm 9.41\end{array}$ & - & - & $\begin{array}{c}27.30 \\
\pm 20.26\end{array}$ \\
\hline Zygophyllum aegyptium A. Hosny & - & 一 & $\begin{array}{c}7.12 \\
\pm 15.92\end{array}$ & - & $\begin{array}{c}22.54 \\
\pm 14.13\end{array}$ \\
\hline Z. album L.f & $\begin{array}{l}80.34 \\
\pm 3.85\end{array}$ & $\begin{array}{c}17.63 \\
\pm 19.48\end{array}$ & $\begin{array}{c}4.02 \\
\pm 5.78\end{array}$ & - & - \\
\hline Z. coccineum $\mathrm{L}$. & 一 & $\begin{array}{c}15.04 \\
\pm 13.13\end{array}$ & $\begin{array}{c}8.41 \\
\pm 18.82\end{array}$ & $\begin{array}{c}9.17 \\
\pm 22.46\end{array}$ & - \\
\hline Z. dumosum Boiss. & - & $\begin{array}{c}44.11 \\
\pm 72.92 \\
\end{array}$ & $\begin{array}{c}6.55 \\
\pm 14.64 \\
\end{array}$ & $\begin{array}{c}28.14 \\
\pm 33.05 \\
\end{array}$ & $\begin{array}{r}31.70 \\
\pm 21.42 \\
\end{array}$ \\
\hline Zilla spinosa (Turra) Prantl & - & $\begin{array}{c}4.68 \\
\pm 8.11\end{array}$ & $\begin{array}{l}17.00 \\
\pm 4.62\end{array}$ & $\begin{array}{c}24.80 \\
\pm 16.85\end{array}$ & $\begin{array}{c}20.60 \\
\pm 10.02\end{array}$ \\
\hline Species richness & 4.5 & 5 & 6 & 4.17 & 4.2 \\
\hline Species turnover & 2 & 3 & 5 & 6 & 5 \\
\hline Shannon $\left(\mathbf{H}^{\prime}\right)$ & $\begin{array}{c}1.92 \\
\pm 0.15 \\
\end{array}$ & $\begin{array}{c}2.44 \\
\pm 0.46 \\
\end{array}$ & $\begin{array}{c}2.82 \\
\pm 0.27 \\
\end{array}$ & $\begin{array}{c}2.74 \\
\pm 0.34 \\
\end{array}$ & $\begin{array}{c}2.33 \\
\pm 0.22 \\
\end{array}$ \\
\hline Simpson (D) & $\begin{array}{c}0.17 \\
\pm 0.03\end{array}$ & $\begin{array}{c}0.1 \\
\pm 0.08\end{array}$ & $\begin{array}{c}0.09 \\
\pm 0.04\end{array}$ & $\begin{array}{c}0.08 \\
\pm 0.04\end{array}$ & $\begin{array}{c}0.1 \\
\pm 0.03\end{array}$ \\
\hline
\end{tabular}

\section{References}

Abd El-Ghani, M. M., and Amer, W.M., 2003. Soil- vegetation relationships in a coastal desert plain of southern Sinai, Egypt. $J$. Arid Environ. 55 (4), 607-628.

Abd El-Ghani, M. M., Salama, F. Salem, B., El-Hadidy, A, and AbdelAleem, M. 2013. Biogeographical relations of a hyperarid desert flora in eastern Egypt. Afr. J. Ecol. 52(2): 173-191.

Abdel Rahman, A.A., Shalaby, A.F., Balegh, M.S. and El-Monayari, M. 1965. Hydroecology of date palm under desert conditions. Bull. Fac. Sci. Cairo Univ., 40, 55-71.

Abu-Taha, M. M. 2010. Habitat and species diversity in some Wadis in Sinai Peninsula. Msc. Thesis, Botany Department, Faculty of Science, Ain Shams University.

Ali, M. E. 2004. On the Ecology of Sinai Peninsula. Msc. Thesis, Botany Department, Faculty of Science, Mansura University.

Biswas, A.K. 1993. Land resources for sustainable agricultural development in Egypt. Ambio. Jour. Human Envir. 22:556-560. 
Boulos, L. 1999. Flora of Egypt: Vol. 1. Al-Hadara Publishing, Cairo, Egypt; 417pp.

-------- 2000. Flora of Egypt: Vol. 2. Al-Hadara Publishing, Cairo, Egypt; 325pp.

-------- 2002. Flora of Egypt: Vol. 3. Al-Hadara Publishing, Cairo, Egypt; 373pp.

------ 2005. Flora of Egypt: Vol. 4. Al-Hadara Publishing, Cairo, Egypt; 325pp.

--------- 2009. Flora of Egypt Checklist. Revised Annotated Edition. Cairo, Egypt: Al-Hadara Publishing, Cairo, Egypt.

Briggs J., Dickinson G., Murphy K., Pulford I, Belal A, Moalla S, Springuel I, Ghabbour S, Mekki A.M. 1993. Sustainable development and resource management in marginal environments: natural resources and their use in Wadi Allaqi region of Egypt. Applied Geography 13:259-284.

Curtis, J. T. and McIntosh, R. P. 1950. The interrelations of certain analytic and synthetic phytosociological characters. Ecology 31: 434445.

Danin, A. 1983. Desert Vegetation of Israel and Sinai. Jerusalem. Cana publishing house; 148pp.

---- 2006. Flora of Israel on line at the web site; http://www.flora.huji.ac.al.

Feinbrun-Dothan, N. 1978. Flora Palaestina. Part III. Israel Academy of Science and Humanities, Jerusalem. 481pp.

1986. Flora Palaestina. Part IV. Israel Academy of Science and Humanities, Jerusalem. 463pp.

Gauch, H. G. and Whittaker, R. H. 1981. Hierarchical Classification of community data. J. Ecol. 69: 135-152.

Girgis, W. A. and Ahmed, A. M. 1985: An ecological study of Wadis of South West Sinai. Egypt. Bull. Desert Inst. 35 (1): 265-308.

Hassan, L. M. 1987. Studies on the flora of Eastern Desert, Egypt. Ph.D, Faculty Science, Cairo University, Egypt.

Helmy, M. A., Moustafa, A. A., Abdel-Wahab, R. H. and Batanouny, K. H. 1996. Distribution behavior of seven common shrubs and trees growing in South Sinai, Egypt. Egypt. Jour. Bot. 36(1): 53-70.

Henderson, P. A. and Seaby, R. M. H. 1999. Community Analysis Package, Version 1.3.1. PISCES Conservation Lt., IRC House, U.K. 
Hill, M. O. 1979. TWINSPAN. A FORTRAN program for arranging multivariate data in an ordered two-way table by classification of the individuals and attributes. Ithaca, New York: Cornell University. $52 \mathrm{pp}$.

Jackson, M. L. 1967. Soil chemical analysis. Printice-Hall of India Private New Delhi, India.

Jafari, M., Chahouki, M. A. Z., Tavili, A. and Azarnivand, H. 2003. Soil-vegetation in Hon-e-Soltan region of Qom Province, Iran. Pak. J. Nutr. 2: 329-334.

Kassas, M., Zahran, M.A. 1965. On the ecology of the Red Sea littoral salt marsh, Egypt. Ecol. Monog. 37: 297-315.

Korkmaz, M. and Ozcelik, H. 2013. Soil-plant relations in the annual Gypsophila (Caryopyhllaceae) taxa of Turkey. Turk. J. Bot. 37: 8598.

Krumbein, W. C. and Sloss, L. L. 1963. Stratigraphy and Sedimentation, $2^{\text {nd }}$ edition Freeman, San Francisco.

Ludwig, J. A. and Reynolds, J. F. 1988. Statistical Ecology: A primer on methods and computing. New York: John Wiley and sons. 337pp.

Magurran, A. E. 2004. Measuring Biological Diversity. Blackwell Science Ltd. Oxford, U.K. 256pp.

Marie, S. M. 1988: Ecophysiological studies on some desert plants. Ph. D. Thesis, Botany Department, Faculty of Science., Al- Azhar University. (Girls Branch).

McAleece, N., Lambshead, J., Patterson, G. and Gage, J. 1997. BioDiversity Professional Version 2.0. The Natural History Museum and the Scottish Association for Marine Science.

McCune, B. and Mefford, M. J. 2005. PC-ORD. Multivariate Analysis of Ecological Data, Version 4.37. MjM Software Design, Gleneden Beach, Oregon, U.S.A.

Migahid, M. M., Kamal S. A., Sadek L. A. 1996. Ecophysiological adaptation of some species in the Mediterranean Desert of Egypt. $J$. Arid Envirn. 34: 11-21.

Morsy, A. A., Hassanein, A. A., Keilani, S. S., and Abu-Taha, M. M., 2010. A Comparative Study on the Vegetation of two Wadis, Sinai Peninsula. Taeckholmia 30: 29-57.

Moustafa, A. A., Klopatek, J. M., 1995. Vegetation and landforms of the Saint Catherine area, southern Sinai, Egypt. J. Arid Envir. 30:385395. 
Moustafa, A. A. and Zaghloul, M. S. 1996. Environment and vegetation in the mountain Saint Catherine, south Sinai, Egypt. J. Arid Envir. 34:331-349.

Moustafa, A. A. and Abdel Wahab R. 2013. Soil fertility in South Sinai, Egypt. Lap Lambert Academic Puplishing.156 pp.

Perkins, J. 1982. Shannon-Weaver or Shannon-Weiner. Jour. Water Poll. Control Fed. 54: 1049-1050.

Pielou, E. C. 1975. Ecological diversity. John Wiley \& Sons, New York.

Piper, C. S. 1950. Soil and plant analysis. University of Adelaide Press, Australia.

Raunkiaer, C. 1934. The life forms of plants and statistical plant geography. Oxford: Clarendon press. $632 \mathrm{pp}$.

Richards, L. A. 1954. Diagnosis and improvement of saline and alkali soils. USDA. Agriculture. Handbook 60. Washington D.C.

Ryan, J., Garabet, S., Harmson, K. and Rashid, A. 1996. $A$ soil and plant analysis. Manual adapted for the west Asia and North Africa region. ICARDA. Aleppo. Syria. 140 pp.

Salama, F. M., Abd El-Ghani, M. M. and El-Tayeh, N. 2013. Vegetation and soil relationships in the inland wadi ecosystem of central Eastern Desert, Egypt. Turk. J. Bot. 37:489-498.

Salama, F. M., Abd El-Ghani, M. M., Gadallah, M., Elnaggar, S. and Amro, A. 2014. Variations in Vegetation Structure, Species Dominance and Plant Communities in South of the Eastern DesertEgypt. Not. Sci. Biol. 6(1):41-58.

Shaltout, K.H., El-Halawany, E.F., El-Garawany, M.M., 1997. Coastal lowland vegetation of eastern Saudi Arabia. Biodiver. Conserv. 6:1027-1070.

Shaltout, K. H. and El-Sheikh, M. A. 2003. Vegetation of the urban habitats in the Nile Delta region, Egypt. Urban Ecosystems 6:205221.

Shawky, R. A. 2010. Comparative ecological studies on xerophytes and halophytes in Sinai Peninsula. Msc. Sci. Thesis, Botany and Microbiology Department, Faculty of Science, Minia University.

Springuel, I., Ali, M. M. 1990. Impact of Lake Nasser on desert vegetation in desert development. Proc. 2 International Desert Development Conference, Cairo, 557-568.

Täckholm, V. 1974. Students' Flora of Egypt. $2^{\text {nd }}$ ed. Cairo University. 888pp. 
TerBraak, C. J. F. and Prentice, I. C. 1988. A theory of gradient analysis. Advan. Ecol. Res., 18: 271-317.

TerBraak, C. J. F. and Smilauer, P. 2002. CANOCO Reference Manual and Cano Draw for Windows User's Guide: Software for Canonical Community Ordination (version 4.5). Microcomputer power (Ithaca NY, USA), 500PP.

Whittaker, R. H. 1972. Vegetation of the Siskiyou Mountains, Oregon and California. Evolution and measurement of species diversity. Taxon, 21: 213-251.

Wilson, M. Y. and Shmid, A. 1984. Measuring beta diversity with presence absence data. J. Ecol. 72: 1055-1064.

Zahran, M. A.1967. On the ecology of the east coast of the Gulf of Suez. I Littoral salt marsh. Bull. Desert Inst. 17(2):225-252. 213-242.

Zahran, M. A. and Willis, A. J. 2009. The Vegetation of Egypt. London, $2^{\text {nd }}$ edition, Springer Publications, Netherlands. 437pp.

Zegeye, H., Teketay D. and Kelbessa E. 2006. Diversity, regeneration status and socio-economic importance of the vegetation in the island of Lake Ziway, south-central Ethiopia. Flora 201: 483-98.

Zhang, Y. M., Chen, Y. N. and Pan, B. R. 2005. Distribution and floristic of desert plant communities in the lower reaches of Atrium River, southern Xinjiang, People's Republic of China. J. Arid Environ. 63(1): $772-84$.

Zohary, M. 1966. Flora Palaestina. Part I. Israel Academy of Science and Humanities, Jerusalem. 364pp.

1972. Flora Palaestina. Part II. Israel Academy of Science and Humanities, Jerusalem. 489pp. 